\title{
Technology for all: turning a keyword into a school subject in post-war Sweden
}

\author{
Magnus Hultén
}

Linköping University Post Print

\section{Tweet}

N.B.: When citing this work, cite the original article.

This is an electronic version of an article published in:

Magnus Hultén, Technology for all: turning a keyword into a school subject in post-war Sweden, 2013, History of Education, (42), 5, 622-637.

History of Education is available online at informaworldTM:

http://dx.doi.org/10.1080/0046760X.2013.832410

Copyright: Taylor \& Francis (Routledge): SSH Titles http://www.routledge.com/

Postprint available at: Linköping University Electronic Press

http://urn.kb.se/resolve?urn=urn:nbn:se:liu:diva-103886 
Technology for all: turning a keyword into a school subject in post-war Sweden

Magnus Hultén

Department of Social and Welfare Studies, Linköping University, 58183 Linköping Email: magnus.hulten@liu.se.phone: +46706040501. 


\begin{abstract}
:
The decades following World War II saw strong technological development, economic growth, and the birth of a consumer society. It also saw 'the advent of technology education', a period of extensive curriculum development in the field. But what was done and why? In order to better understand the historical roots of primary and lower secondary technology education, the mid-century school reforms in Sweden are examined, more specifically the birth of the new subject of Technology (Teknik) in compulsory schools. This article wants to emphasise the political driving forces behind the introduction and shaping of this new subject. In a time of rapidly transforming educational systems and labour markets, the term teknik proved to be a useful concept for policy makers and reform technocrats. But despite the liberal arts education aims, the subject came to recreate the inequalities of the differentiated school systems within the framework of a school 'for all'.
\end{abstract}

\title{
Keywords:
}

Educational Change; Educational Planning; Educational Policy; Technology education; Industrial arts. 
The decades following World War II, sometimes referred to as 'the golden age', 'the age of affluence' or 'the long 1950s', saw strong technological development, economic growth, and the birth of a consumer society. The atom and the fields of automation and astronautics became symbols of technological progress and technology itself became a buzzword. ${ }^{1}$ Educational systems around the world changed drastically during the decades following World War II; changes not only triggered by technological development, stronger economies, and the absence of war, but also of rising populations and democratic and egalitarian movements. ${ }^{2}$ Along with new institutions and regulations states grew and 'planning' almost 'became the political religion of post-war Europe'. ${ }^{3}$

The general purpose of this article is to study how periods of rapid social change and industrialization affect the educational system at primary and secondary level, and

\footnotetext{
${ }^{1}$ The decades following World War II can be demarcated differently depending on which factors are considered - cultural, economic etc. Booker uses 'the long fifties' to designate the period of 1946-1964 with respect to its 'American Cold War hysteria' and the special type of science fiction that came out of this. M. Keith Booker, Monsters, Mushroom Clouds, and the Cold War (Westport, Connecticut - London: Greenwood Press, 2001), 3. 'Age of affluence' is a term used by Tony Judt on the period 1953-1971. Tony Judt, Postwar: a history of Europe since 1945 (New York: Penguin Press, 2005). Eric Hobsbawm uses 'the Golden Age' on the period 19501973.

${ }^{2}$ Henry M. Levin, 'The Dilemma of Comprehensive Secondary School Reforms in Western Europe,' Comparative Education Review 22, no. 3 (1978), 434-451.

${ }^{3}$ Judt. On Sweden, see Per Lundin and Niklas Stenlås, 'Technology, state initiative and national myths in cold war Sweden' in Science for welfare and warfare: Technology and state initiative in cold war Sweden, eds. Per Lundin, Niklas Stenlås and Johan Gribbe (Sagamore Beach: Science history publications, a division of Watson Publishing international LLC, 2010).
} 
especially so the content of schooling. ${ }^{4}$ In the post-war period education became more and more an instrument for societal planning, social engineering and economic development in the west. At the same time governments in Western Europe aimed at democratizing their educational systems in order to even out social differences and educational opportunities. ${ }^{5}$ How was this dual purpose solved within the framework of primary and lower secondary education?

I will argue that Swedish post-war compulsory education incorporate two largely incommensurable notions of technology, one being as applied science and of high status (primarily in the Science study subjects) and the other a 'technology for all' in focus of this study, of low status and incorporated in the subject Teknik. As Popkewitz has argued, '[s]chool subjects were not invented to teach music or science per se, but were assembled as converting ordinances in relation to modes of life. ${ }^{6}$ This article is a study of the political and educational discourses that shaped and gave birth to the Swedish school subject Teknik, introduced in the nine years state controlled compulsory school in 1969.

In this study I want to stress the conceptual point of view. This means an extra focus on changing conceptual frameworks available to actors and how these affected their understanding of and actions in the world. ${ }^{7}$ Technology, as a concept, started

\footnotetext{
${ }^{4}$ This being said, changes in educational discourses are of course not exclusively tied exclusively to these periods in history, but a more general phenomena. Eg. Thomas S. Popkewitz, 'Curriculum history, schooling and the history of the present,' History of Education, 40, no. 1 (2011).

${ }^{5}$ Levin.

${ }^{6}$ Popkewitz, 15.

${ }^{7}$ The conceptual approach is discussed in for example Melvin Richter, 'Reconstructing the History of Political Languages: Pocock, Skinner, and the Geschichtliche Grundbegriffe,' History and Theory 29, no. 1 (1990), 47; Reinhart Koselleck, The practice of conceptual history (Stanford,
} 
gaining importance already in the late 18th and 19th century, out of a need for systematic reflection on industrialization. ${ }^{8}$ A development that changed 'technology' from being rarely used to becoming 'the central issue of our civilisation' in mid 20th century. ${ }^{9}$ But it was not a continuous development in form of a ready made concept steadily growing in importance, instead, the real boost for the English term 'technology' sprung out of a reconceptualization in the early 20th century. While technology, as it was used in the 19th century, can best be characterized as a field of study concerned with the practical arts, the real break through was tightly linked to the fact that technology was turned into the object of study, and that 'technology' was seen as a feature of modern society. ${ }^{10}$ More precisely, Schatzberg has argued that:

California: Stanford University Press, 2002). In relation to history of education, see Jan Masscheleina and Maarten Simons, 'Do historians (of education) need philosophy? The enlightening potential of a philosophical ethos,' Paedagogica Historica, 44, no. 6 (2008).

${ }^{8}$ Joost Mertens, 'Technology as the science of the industrial arts: Louis-Seacutebastien Lenormand (1757-1837) and the popularization of technology,' History and Technology 18, no. 3 (2002). Jan Sebestik, 'The rise of the technological science,' History and Technology 1, no. 1 (1983).

${ }^{9}$ Sebestik, 41.

${ }^{10}$ Eric Schatzberg, 'Technik Comes to America: Changing Meanings of Technology before 1930,' Technology and Culture 47, no. 3 (2006), 486ff; Leo Marx, 'Technology: The Emergence of a Hazardous Concept,' Technology and Culture 51, no. 3 (2010), 562, 575. Originally published: Leo Marx, 'Technology: The Emergence of a Hazardous Concept,' Social Research 64, no. 3 (1997). See also Ruth Oldenziel, Making technology masculine: Men, women and modern machines in America 1870-1945 (Amsterdam: Amsterdam University Press, 1999), 14f, $20 \mathrm{ff}$. John R. Pannabecker, 'Diderot, the Mechanical Arts, and the Encyclopédie: In Search of the Heritage of Technology Education,' Journal of Technology Education 6, no. 1 (1994), 52, and Sebestik, 31f. 
[Technology] attained the status of "keyword" only in the 1930s, and [...] before this time, issues that historians now discuss in terms of technology were framed in such terms as useful arts, manufacturing, industry, invention, applied science, and the machine. In other words, when historians now address "attitudes toward technology" before 1930, they are employing an analyst's category not used by the historical actors themselves. ${ }^{11}$

In relation to educational practices, this means that addressing technology education before 1930 means addressing a phenomenon that the actors themselves had not discerned, at least not in a modern sense of the term. Marx frame the conceptual problem as a 'striking interdependence (or reflexivity) in the relations between certain keywords and fundamental changes in society and culture'. ${ }^{12}$ Sometimes the changes we study coincide with new meanings in the very concepts we use in order to study that same changes.

\section{Post-war science and technology education}

In research on post-war curricular reforms in primary and secondary education, much focus has been directed towards science and mathematics. The Sputnik chock gave significant momentum to the existing efforts, but the need for revised curricula in these subjects had been discussed early on in the post-war period. ${ }^{13}$ Terzian argues that already the New York World's Fair in 1939-1940 symbolizes 'a turning point when the Progressive purposes of science education began to give way to "manpower" and "professionalist" ends that aligned with the nation's economic and military

\footnotetext{
${ }^{11}$ Schatzberg, 486

${ }^{12} \operatorname{Marx} 2010,563$.

${ }^{13}$ Albert V. Baez, Innovation in science education: world-wide (Paris: The Uniesco Press, 1976), 70f; John L. Rudolph, Scientists in the Classroom: The Cold War Reconstruction of American Science Education (New York: Palgrave, 2002).
} 
imperatives'. ${ }^{14}$ But as John Rudolph has shown, it was not only an elite response to a perceived lack of well educated scientists needed in the American technological race against the Soviet Union, but also came to develop a broader and more inclusive conception of science in a liberal arts education tradition. ${ }^{15}$ At the same time, the taste of real science was ambiguous. In the words of Rudolph:

\begin{abstract}
One might say that the public was brought into the laboratory in order to keep them out in a preemptive move of sorts. For what the public really saw was not the messy, conflicted workplace populated by researchers, administrators, and military contractors, but rather a tidy little anteroom arranged to look like a laboratory housing scientific work as the scientists imagined it could be, or should be. The point was to make sure that visitors would not be inclined to wonder what lay behind the far door. ${ }^{16}$
\end{abstract}

While this 'tidy little anteroom' clearly strengthened the cultural status of science in society, it did not provide a critical training from the point of view of the citizens not pursuing scientific careers. The conclusion Rudolph draw is that what 'has been neglected in historical studies of science and education, though, is an appreciation of the extent to which the disciplinary subject matter itself (and above all the specific process of curriculum development or the organization of the school day) has been shaped by external forces'. ${ }^{17}$

Technology education at primary and secondary level has not received the same attention as science education. This is partly due to a neglect among historians. As

\footnotetext{
${ }^{14}$ Sevan G. Terzian, 'The 1939-1940 New York World's Fair and the Transformation of the American Science Extracurriculum,' Science Education, 93, no. 5 (2009), 892.

${ }^{15}$ Rudolph, 169f. Also see Magnus Hultén, Naturens kanon: formering och förändring av innehållet $i$ folkskolans och grundskolans naturvetenskap 1842-2007 (PhD diss.: Stockholm university, 2008), 194f.

${ }^{16}$ Rudolph, 196.

${ }^{17}$ Ibid., 198.
} 
Petrina has remarked in relation to previous research on technology education, 'except for the training of engineers, historians of technology ignore education'. ${ }^{18}$ What is known, though, is that it was in the decades following World War II that the ideas for a comprehensive type of technology education began to form. ${ }^{19}$ Zuga talks about the 1960s and 1970s as "the advent of technology education", a period of extensive curriculum development in the field. ${ }^{20}$ A triggering factor is said to be 'the new 50 percent,' a growing group of pupils that needed something in-between vocational and academic training, a new type of general education. ${ }^{21}$ One of the main explanations given to the birth of the field in the post-war period is that technology brought a theoretical funding to the practical and vocational traditions in school. ${ }^{22}$

${ }^{18}$ Stephen Petrina, 'Sidney Pressey and the Automation of Education, 1924-1934,' Technology and Culture 45, no. 2 (2004), 306.

${ }^{19}$ Dennis R. Herschbach, 'From Industrial Arts to Technology Education: The Search for Direction,' Journal of Technology Studies 23, no. 1 (1997), 24.

${ }^{20}$ Karen F. Zuga, 'An Analysis of Technology Education in the United States Based Upon an Historical Overview and Review of Contemporary Curriculum Research,' International Journal of Technology and Design Education 7, no. 3 (1997), 207. See also Senta A. Raizen, “Making Way for Technology Education,” Journal of Science Education and Technology 6, no. 1 (1997), 59f; Dennis R. Herschbach, "From Industrial Arts to Technology Education: The Eclipse of Purpose," Journal of Technology Studies 23, no. 2 (1997), $20 \mathrm{f}$.

${ }^{21}$ Dennis R. Herschbach, “'What Is Past Is Prologue': Industrial Arts and Technology Education,” Journal of Technology Studies 22, no. 1 (1996), 29. Also see John Williams, 'Technology Education in Australia: Twenty Years in Retrospect' in International Handbook of Technology Education: Reviewing the Past Twenty Years, eds. Marc J. deVries and Ilja Mottier (Rotterdam/Taipei: Sense Publications, 2006).

${ }^{22}$ Herschbach, 'The Search for Direction,' 30. 
America, Germany, and the Soviet Union have been described as countries where a general type of technology education was developed early on. The American projects of the 1960s were directed towards industry, focusing on manufacturing and construction, as in the American Industry project and in the Industrial Arts Curriculum Project. ${ }^{23}$ In West Germany, a new subject, Arbeitslehre, was introduced in 1964, a subject best understood as an updated industrial arts education, aimed at developing craft techniques. ${ }^{24}$ In the former Soviet Union and in East Germany, the idea of polytechnic education was renewed in the 1950s. The aim was to emphasise the role of technology in the development of the socialist society in compulsory education. ${ }^{25}$ Polytechnic education, as it developed in the late 1950s and early 1960s, was not a single subject, but the alignment of subjects such as History, Physics, Chemistry, Geography etc. towards production and the field of technology. ${ }^{26}$ The polytechnic idea, which was already important in the early history of the Soviet Union, drew on Marx and his analyses of the industrial society, more specifically on the division of labour,

\footnotetext{
${ }^{23}$ Theodore Lewis, 'Content or Process as Approaches to Technology Curriculum: Does It Matter Come Monday Morning?' Journal of Technology Education 11, no. 1 (1999).

${ }^{24}$ Gerd Hoepken, 'Stages of 30 Years of Technology Education in Germany' in International Handbook of Technology Education: Reviewing the Past Twenty Years, eds. Marc J. deVries and Ilja Mottier (Rotterdam/Taipei: Sense Publications, 2006).

${ }^{25}$ S. G. Shapovalenko, 'The Tasks, Principles and Scope of Polytechnical Education in Soviet Schools' in Polytechnical Education in the U.S.S.R., ed. S. G. Shapovalenko (Paris: UNESCO, 1963), 108f; Publications of the Government of the German Democratic Republic, Education and Training in the German Democratic Republic (Staatsverlag der Deutschen Demokratischen Republik, 1966), 88ff.
}

${ }^{26}$ S. G. Shapovalenko, ed., Polytechnical Education in the U.S.S.R. (Paris: UNESCO, 1963), part II. 
regarding the nature of work in this type of society and the consequences of this for elementary education (even though Marx himself probably did not use the concept). ${ }^{27}$

Even though it is clear that previous research on technology education has described the more general context of the time that this field was born, what has not been clearly shown is (with reference to Rudolph's claim above) the politics of this transformation, nor the extent to how the conception of technology itself changed in this.

\section{Technology as applied science}

Teknik was a concept of growing political importance in post-war Sweden. A sign of this was the conference Tekniken och morgondagens samhälle (Technology and the Society of Tomorrow), held in November 1955, gathered leading scientists, industrialists, unionists, economists as well as the prime minister as speakers, a conference that attracted a lot of media attention. ${ }^{28}$ The tight link between politics, technology and science, and between these and economic development, strengthened the conception of technology as applied science, and as a central object for the planning of the future. Significant of this obsession with technology as a marker for the society of tomorrow is the radio programs made by state radio in informing the Swedish population about the new nine years compulsory school that was being developed in the 1950s, and that was to unite the school system at these levels and making it state controlled. In the first of three programs, broadcasted in 1958, the school of tomorrow is

\footnotetext{
${ }^{27}$ Robin Small, 'The Concept of Polytechnical Education,' British Journal of Educational Studies 32, no. 1 (1984); M. N. Skatkin, 'Soviet Experience in Polytechnical Education Before the Reform (1917-1958)' in Polytechnical Education in the U.S.S.R., ed. S. G. Shapovalenko (Paris: UNESCO, 1963).

${ }^{28}$ Lundin and Stenlås.
} 
set first by a background of the old school, then through a long section devoted to the computing machine (matematikmaskin) and its growing importance in the society of tomorrow. The computing machine then is turned into the symbol for the demands on future citizens and the implications for the content of schooling are discussed, but also contested by a contribution from professor Torsten Husén, leading pedagogue of that time, who refers to the 'Sputnik psychosis' when addressing the need to withstand the demands of the time to increse the scientific and mathematic content of schooling. ${ }^{29}$

In Swedish policy documents, commission reports and curriculum drafts from the late 1950s concerning compulsory education (primary and lower secondary education), the discourse on teknik was mostly linked to science, through 'science and technology'. The importance of 'science and technology' was stressed again and again, both with regard to the need for knowledge in these fields among citizens and the need to strengthen the enrolment to higher education within these fields. But, even though upper secondary and higher technical education expanded during this time the rhetoric of 'science and technology' at compulsory school level (grades 1-9, ages 7-15) was primarily a question of strengthening Science and Mathematics. These areas were the bases for further education within the field of engineering (ingenjörsutbildning) in Sweden (upper secondary and tertiary technology education), and continued to be so also after the post-war period. In the 1930s, engineering education had already become a tool for societal change for the Social Democrats, governing the country at that time. In this type of education they saw a possibility for increased participation of the

\footnotetext{
${ }^{29}$ The program is available on http://sverigesradio.se/sida/artikel.aspx?programid=1602\&artikel=817716. Accessed the 23 July 2013.
} 
working class in higher education, and thus a way to make the classes co-exist in a more egalitarian fashion. $^{30}$

In line with the notion of technology as applied science, engineers' interest in primary and lower secondary schooling during the decades following the second world war was almost entirely restricted to the school subjects Science and Mathematics. But even these subjects got little attention. For example, in Teknisk tidskrift and Ny teknik, the journals of the Swedish Association of Graduate Engineers at that time, the 1969 reform of the nine years compulsory school is mentioned once, in a very short paragraph containing just over 50 words, about Mathematics. And this despite the fact that a new technical subject, named Teknik, was introduced with the 1969 national curriculum. More specifically the short paragraph contains a citation from the 1967 proposal for a new national curriculum where the National Board of Education (Skolöverstyrelsen) display self criticism in relation to achieved ends in mathematics education. ${ }^{31}$ This obviously satisfied the engineers, as they were not content with the mathematical skills of students entering engineering education.

The conception of technical knowledge as applied science and as not suited for compulsory education was for a time shared by the school authorities and commissions responsible for the educational reforms in post-war Sweden. But something started to happen as the (full) political potential of the term teknik began to emerge.

\section{The political potential of teknik in relation to the vocational field}

\footnotetext{
${ }^{30}$ Lennart Schön, Sweden's road to modernity: An economic history (Stockholm: SNS Förlag, 2010), 281ff, 314ff; Boel Berner, 'The worker's dream of becoming an engineer,' History and Technology 15, no. 4 (1999).

31 'Läroplansöversyn - Grundskolan,' Ny teknik 2, no. 7 (1968), 5.
} 
The mid-19th century was a time of great reforms in primary and secondary education in Sweden. As a consequence of the reforms, the Swedish state strengthened its control over primary and secondary education, and the legislation regulating education grew drastically, culminating in the 1970s, when most educational activities at these levels where state controlled. ${ }^{32}$ The main rationale behind the reforms was to unify the school system so that social differences could be evened out. ${ }^{33}$ The politicians emphasised the need to develop a national curriculum, to be taught in every classroom at compulsory level of education. The task of deciding what to include in such a curriculum was not easily solved, as it required compromises. The different school forms that existed at this level in Sweden prior to the reforms differed significantly in what they included in their curricula. In relation to lower secondary education, grades $7-9$, this was especially so. On the one hand there existed a broad range of vocational schools at these levels, primarily directed to the working class. On the other hand there was the more academically oriented schools. How to incorporate both these traditions into a new, common and state controlled school became a great task for politicians and post-war educational committees in Sweden.

The political power in Sweden shifted during this time, and a long era of continuous government of the Social Democrats began. They were to hold power in various constellations until 1976. The school grew to be one of their main areas of reform. ${ }^{34}$

\footnotetext{
${ }^{32}$ Bo Rothstein, Den socialdemokratiska staten - reformer och förvaltning inom svensk arbetsmarknadsoch skolpolitik (Lund: Arkiv avhandlingsserie 21, 1986), 166.

${ }^{33}$ Ibid., $91 \mathrm{f}$.

${ }^{34}$ Ibid., 161ff; Gunnar Richardson, Drömmen om en ny skola: idéer och realiteter $i$ svensk skolpolitik
} 1945-1950 (Stockholm: Liber, 1983), 49. 
A factor influencing the course of reform in the 1940s and 1950s was the growing number of children attending academically oriented study paths (cf. 'the new 50 percent'). From a political perspective, this was seen as a potential threat to the supply of manual workforce. The industries need for manpower in Sweden reached its highest point ever in both absolute and relative terms during this time, culminating in the 1960s, and on top of this, the failure rates for pupils attending academically oriented study paths were high. ${ }^{35}$

A fact complicating the political solutions to this educational problem was the strong belief in rational choice in the Swedish post-war political culture. It was believed that if the right information were given the citizen, the citizen would be able to make the right choice. For example, in school, a school counselor provided the children with information about different choices. In some cases, children were offered questionnaires and as a result could find out what educational pathways to pursue. However, in reality, children could choose whatever study path they wanted as no special entry requirements were stipulated.

It was in the efforts of making the of the vocational and general vocational fields more popular among children that the concept of teknik came to play a central role. Sweden, as many countries during these decades, were going to a radical transformation in the labour market with growing productivity and growing knowledge-intensive industry as well as unskilled work. ${ }^{36}$ Not only the pupils' interests and attitudes towards different fields were surveyed, but also inventories of occupations and ways of grouping these into vocational branches and calculations of societal needs were made during this

\footnotetext{
${ }^{35}$ Schön, 321; Stellan Arvidson, 'Demokratins skolprogramme' in Människan och samhället : en bok till Tage Erlander på 50-årsdagen, (Stockholm: Tidens förlag, 1951), 14f.

${ }^{36}$ Schön, 322ff.
} 
time by the technocrat committees. teknik became an important concept in structuring different vocations in these lists.

Another sign of the growing importance is found in relation to the experimental trials (försöksverksamheten) performed during the 1950s, where new solutions to the new nine years compulsory school were tested out. ${ }^{37}$ A technical sector, 'teknisk sektor' as it was called, was tested for the first time in school year of 1957/58. It attracted only a small percentage of pupils. The following school year, 1958/59, a new programme in this sector was introduced into two counties in Sweden, a programme that aimed at attracting pupils with a talent in science and mathematics, but who had little interest in language, and therefore did not fit well with the theoretical programme, as that required substantial language study. ${ }^{38}$ Already by the following school year, this programme grew to take nine percent of pupils and it was expected to grow even bigger. Although this popularity gave a momentum to teknik as a vocational field, it is clear that a fair part of the popularity was thanks to the content of the programme, that is science and a reduced language course, thus a notion of technology as applied science.

It was the National Board of Education that was responsible for the experimental trials and thus for the possible implications these trials might have for the work that was done by technocrat committees and other actors involved in the educational reforms during that time. The Board was the central administrative authority for primary and secondary education, an administration that grew in importance during the reforms studied. The Board, formed in 1920, executed and followed up reforms and took care of in-service education, etc.

\footnotetext{
${ }^{37}$ Sixten Marklund, Skolsverige 1950-1975 : Del 2 : Försöksverksamheten (Stockholm: Liber, 1981), 25, 97.

${ }^{38}$ Ibid., $70 f$.
} 
A letter was sent out in June 1960 to groups involved in the changes in the educational system and that the Board saw as important for technology education (teknisk utbildning), among them the so called 1957 Committee that had got the task of designing a final solution to the nine years compulsory school. In the letter, the Board describes how a technical sector has been tested in schools involved in the extensive trials, and that a new programme $8 \mathrm{c}$ had proven especially successful. The programme had a focus on mathematics, physics, chemistry and the Swedish language. In the letter the Board explicitly explains that no technical subjects (tekniska fackämnen) were included in the programme, as such subjects would have made the programme too specialised. ${ }^{39}$ They also explain how the programme was supposed to fit with the technological education planned for upper secondary level (not engineering education) and they requested the actors addressed in the letter to consider how this might affect their work. In the words of the Board:

With respect to the very large need for technically educated employees, the Board wants, again, to emphasise the importance of primary and secondary technology education [teknisk utbildning].

School authorities and other stakeholders in relation to technology education shall explore if the pre-training for upper secondary technology education is arranged in a satisfactory way and if parents and pupils are enough informed about the possibilities that these types of educational paths offer. ${ }^{40}$

Technical programmes were introduced in grade nine with the first national curriculum of the nine years compulsory school, grundskolan, in 1962. But despite the

\footnotetext{
39 'I 440: Riktlinjer rörande den förberedande och därpå byggande tekniska utbildningen. 1960-07-29’, 1957 års skolberedning SE/RA/321818/27, 1.

${ }^{40}$ Ibid., 3.
} 
recommendations of the Board not to include technical subjects in the syllabuses, such a subject was created, and it became very popular among children, especially boys.

$[A] n$ educational area that has attracted much attention from pupils and parents this last year is the technical, more precisely, the elective subject technological orientation. ${ }^{41}$

Technological orientation (teknisk orientering), created as an elective subject in grade eight and that led to several different technical programmes in grade nine, was a subject that attracted much attention, both from officials, parents and pupils. It was also getting attention in media. The articles often emphasized the general character of the pedagogic ideas and seldom the technical content as such, meaning that the subject came to be portrayed as a general subject, and in line with the Progressive Education ideals of that time. $^{42}$

At the time of the first revision of the national curriculum of grundskolan, initiated in early 1966, the subject Technological orientation was high on the agenda for this reform. One of the main problems that the officials at the Board had identified was that the election system had become too complicated. ${ }^{43}$ The system with programmes, constructed to facilitate an individualized compulsory curriculum and preparing students for different vocational or academic paths were removed, and the elective parts in grades 7-9 were reduced to a choice between only four subjects: a third language (Språk, at that time, French or German), Technology (Teknik), Economics (Ekonomi) or

41 'Ang revision av läroplan för grundskolan 1965-12-01', Läroplansarbete för grundskolan, Lgr 69 SE/RA/420262/29/F I a, vol. 2, 15.

${ }^{42}$ Example: “Emmabodapremiär på onsdagen för märklig film på temat glas” Barometern March 23 (1967), 4 and "Premiärvisning i Emmaboda på expertfilm för skolorna" (1967). The last article of unknown date and journal.

43 ‘Ang revision av läroplan,' 14f; Bengt Cullert, Med folkskolans pedagogik som riktmärke: minnesanteckningar från grundskolans tillkomst och första årtionde (Stockholm, 1986), 144f; Skolöverstyrelsen, Läroplansöversyn grundskolan (Stockholm: SÖ-förlaget, 1967), 26f. 
$\operatorname{art}($ Konst). As a result of these changes, the aim of the elective parts of grundskolan broadened and gave a momentum of change in a general direction for the technical field (Teknisk orientering changed name to Teknik with the 1969 curriculum, which I will come back to).

The reason for the technical and economic sectors being represented among the elective courses seems to have been largely due to their popularity. Out of the vocational sectors present in the 1962 national curricula, the technical sector had attracted a far larger proportion of pupils, more than 20 percent, compared with that of the second largest sector, economics, which attracted 10 percent. ${ }^{44}$ This was in the mid1960s and meant that out of the broad vocational fields represented in the programmes of grade nine in the trails of a new compulsory school in the 1950s, only technology and economics were left, which in some respect means that technology now had become the heading for the whole of the mechanical/practical/industrial/crafts field at this level of the school system. A factor behind the transformed width of the term teknik at these levels of the educational system seems to be that it was perceived to be fairly neutral, for example that is that it was not perceived to favour any particular vocational branch. ${ }^{45}$ Teknik could be used as a concept able to unite different vocational sectors under one new heading.

Another political factor that contributed to the broadened conception of teknik was the rising gender awareness among policy-makers. From a gender perspective, this time in Swedish educational history is characterized by gender polarized discourses being challenged to an increasing extend. In the political debate in 1962, a girl choosing technology education stood out as a symbol of a pupil making a gender-crossing

\footnotetext{
${ }^{44}$ Skolöverstyrelsen, Läroplansöversyn grundskolan, 18.

${ }^{45}$ Interview with Thore Gårmark, 28th of August, 2011.
} 
choice. ${ }^{46}$ Also, and in parallel to international trends, the work of women in homes came to attract political attention during the first half of the 20th century. In Sweden, the women movements joined forces in around a more rational approach to the work of the housewife. They thought they were lagging behind men in the developments. New machines were to be used in homes. The dishwasher, the vacuum cleaner etc. became, together with a more rationally and ergonomically ordered kitchen, symbols of the modern housewife in the Swedish welfare state, folkhemmet. ${ }^{47}$ All in all, there definitely existed a momentum of change in the gendered area where concepts such as teknik would prove to be handy. And the other way around, the gender discussion clearly broadened the conception of teknik in Swedish educational policy discourse.

But despite the general aims, Teknik became a subject chosen almost exclusively by boys, typically boys with a working class background. The broadened notion of Teknik was not so easily transferred into school practice. Granlind, one of the first female teachers in this subject in Sweden, remembers having wild discussions with the boys in her class in the 1970s about girls and technology: "technology [teknik] is scooters," they claimed and concluded: "girls should not do technology". 48

\footnotetext{
${ }^{46}$ Maria Hedlin 'How the Girl Choosing Technology Became the Symbol of the Non-Traditional Pupil's Choice in Sweden.' Gender \& Education 23, no. 4 (2011).

${ }^{47}$ Jan-Erik Hagberg. Tekniken i kvinnornas händer: hushållsarbete och hushållsteknik under tjugo- och trettiotalen (PhD diss.: Linköping University, 1986); Brita Lövgren. Hemarbete som politik: diskussioner om hemarbete, Sverige 1930-40-talen, och tillkomsten av Hemmens Forskningsinstitut (PhD diss.: Stockholm University, 1993); Ruth Oldenziel and Karin Zachmann. 'Kitchens as Technology and Politics: An Introduction' in Cold War Kitchen: Americanization, Technology, and European Users, eds. Ruth Oldenziel and Karin Zachmann (Cambridge, Massachusetts, London, England: The MIT Press, 2009).

${ }^{48}$ Interview with Barbro Granlind on 12th of February, 2009.
} 


\section{Conceptual considerations by actors of that time}

Something that has not yet been addressed in this article is the fact that most continental European Languages have two distinctly different terms that are commonly translated into technology. Teknik and teknologi, are the two concepts used in the Swedish language. The choice of using the term teknik could not have been obvious to the actors. Taking the normal use of concepts in Sweden in the 1950s, teknologi, although not as common a word as teknik, would have been the more natural choice when naming a school subject. First, Teknology existed as a school subject at this level of the school system in the late 1950 s, more specifically as a subject in programmes directed towards metal trades. ${ }^{49}$ Teknologi was a subject made out of a number of sub subjects, namely Work safety, Practical chemistry and Physics, Material science, Tools and machines. Second, a subject called Teknologi was later introduced in upper secondary technical education, tekniskt gymnasium, in 1966. The 1960 upper secondary school committee (1960 års gymnasieutredning) that had suggested Teknologi in 1963 described it as follows: 'technology [teknologi] is to provide students with basic knowledge in core subjects to the technical field by bringing knowledge material from several disciplines together and to emphasize the relationship between these'. ${ }^{50}$ On top of this, the term Teknisk orientering was criticized immediately, specifically, by the all-important National Board of Education, responsible for executing and following up reforms. They

\footnotetext{
${ }^{49}$ Example Gösta A. Karlsson and Vulf Wohrne, Teknologi: grundkurs för metallyrken för enhetsskolan och den grundläggande yrkesutbildningen vid yrkesskolorna (Stockholm: Tidens förlag, 1957).

${ }^{50}$ SOU 1963:43, 413. The subject contained 'a collection of the basic technical subjects mechanics, solid mechanics, technical drawing, production and material science'. For the content of this subject, see for See Stellan Engström and Kjell Malm, Teknologi : Gymnasiet År 1 Och 2 :

Lärarhandledning (Stockholm: SÖ-förlaget, 1966).
} 
claimed that the term was inappropriate, as orientering signalled that no proper knowledge was to be acquired in this subject. ${ }^{51}$

The nomenclature and definitional problems surrounding technology education, and especially the school subject Technological orientation, points to the fact that no established practice existed at these levels of the school system. It also points to the broader discussion about suitable names for programmes and subjects of that time. The 1957 Commission did not especially comment on Technological orientation, but it is clear that the naming played an important role in its work. In terms of subject names, the committee claimed to have followed the following principles:
[W]hen seeking to achieve a satisfactory name for the individual subjects, one must often compromise between the requirement of getting an accurate description considering the overall subject matter, while on the other hand, the requirement that the name should be short and easy to use. The Commission has taken the view that the latter requirements should play a crucial role in determining a subject's name. The subject matter should be demarcated and described elsewhere. ${ }^{52}$

That is, the name of a subject was not necessarily constructed to reflect subject matter, an important fact for the development and introduction of the subject Teknisk orientering as this show that the committee was fairly open minded when it came to creating new subjects not necessarily existing in the school system. Despite that Teknisk orientering was considered as an unsuitable name, Teknologi never resurface as an alternative. The main reason for this was probably that Teknologi became associated with upper secondary technical/engineering education, and was seen a having a too specialized content for compulsory education. Only a few percent of the pupils

\footnotetext{
${ }^{51}$ Skolöverstyrelsen, Utdrag ur Kungl. Skolöverstyrelsens utlåtande över 1957 års skolberednings betänkande (Stockholm: Skolöverstyrelsen, 1961), 37.

${ }^{52}$ SOU 1961:30, 194.
} 
continued to study the type of upper secondary technical education that contained Teknologi.

However, not everybody was satisfied with the development and with teknik becoming the prime way of referring to the vocational sector. Swedish Vocational School Association (Svenska yrkesskolföreningen), created in 1923 to unite different actors - private, municipal and state - in the vocational field, belonged to a type of actors that got less influential during the post-war reforms, as the state took control over most of this type of education. In their journal Tidskrift för praktiska ungdomsskolor there was a long discussion on 'yrkes' (vocational/craft) becoming seen as more and more obsolete as a concept for the field. The journal notes that the old names for vocational education 'do not seem trendy these days' and continues 'it cannot be that simple, that it's only about getting a new name that sounds better in the ears of the parents than those terms loaded with "vocation" and that brings to the mind the odour of used blue collar'. ${ }^{53}$ This touches on the whole discussion that surrounded the dichotomy of theoretical-practical and the need to give higher status to the practical field in order to secure the supply of manual workforce. Even though the concept teknik was perceived by many to bring something new and fresh into the vocational field, one must give Association right in their observation that 'it cannot be that simple, that it's only about getting a new name that sounds better'. I the concluding section I will argue that the 'technology for all' developed can be further problematized from a class perspective.

\section{Technology for all}

The development of technology as a general field of knowledge took part in the mid 1960s, at the time of the first revision of the national curriculum of grundskolan. Actors at the National Board of Education began arguing that it was not to be considered as a

\footnotetext{
${ }^{53}$ K. A., 'Mellanformerna,' Tidskrift för praktiska ungdomsskolor, no. 3 (1961), 105.
} 
vocational subject but as a general subject, perhaps the most general subject in compulsory school. It was as if there was technology (teknik) everywhere one looked in the 'traditional' curriculum. Or as expressed in a syllabus draft from December 1968 for the subject Teknik:

The basic materials for teaching [in Teknik] is thus almost incalculable and can not be defined, because you can not draw the dividing lines between technology and other fields or between technical and non-technical products and tasks. The opaqueness of the teaching material increases with technological progress and developments in other areas. ${ }^{54}$

This illustrates the scope of the concept of technology in a compulsory education context at that time. The growing contemporary notion of a world dominated by technology interacted with the curricular reforms. The need for future citizens to have knowledge related to technical aspects of the world was acknowledged and it is also clear that this demanded a new conception of primary and lower secondary technology education, not yet addressed in the fields normally related to technological knowledge such as engineering or vocational education.

To understand the 'incalculability' of the technical field in relation to the compulsory curriculum one must recognize the fact that even though the subject Teknik was a post-war construct, the technically related field was not new to these levels of the school system. Hallström has argued that the early 20th century Swedish elementary education curriculum saw a significant increase in technical content, a development in which '[r]epresentatives of the Government were prime movers in enhancing the significance of technology in school together with teachers, while engineers generally

\footnotetext{
54 'Förslag till kursplan med anvisningar och kommentarer i tillvalsämnet teknik 1968-12-12', Läroplansarbete för grundskolan, Lgr 69, SE/RA/420262/29/F I a, vol. 6, appendix 5, 5.
} 
showed little interest. ${ }^{55}$ However, it was a development in which the actual term teknik was rarely used. It is only with the eyes of a modern conception of teknik that a technical content can be discerned in early 20th century elementary education. Never the less, the early 20th century educational reforms contributed to the discursive fundaments for a technical field in post-war compulsory education.

In the transformation of the vocationally oriented subject Teknisk orientering to the generally aiming subject of $T_{e} k n i k^{56}$ it becomes clear that there were no raw-models to draw on, for example no academic disciplines to model the subject on. For example, one can note that the technical sub-subjects included in the 1962 syllabus of Technological orientation were not considered suitable as a core content of Teknik, instead they were listed as subjects connected to Teknik just as any other school subject in the national curriculum. The subject Teknik was in fact not primarily defined through its content but through its focus on technological products, processes and services (figure 1). It is therefore hard to characterise the subject in terms of content. Rather, it appears as a tool for linking the traditional subjects, and their respective contributions to (or perspectives on) the technical field, together. Everything that provided knowledge relevant to a technical product, process, or service was included. In this way Teknik became a vehicle for bringing into focus the technically relevant content already present

\footnotetext{
55 Jonas Hallström, 'Technical knowledge in a technical society: elementary school technology education in Sweden, 1919-1928,' History of Education, 38, no. 4, (2009), 455.

${ }^{56}$ On the development Teknisk orienterin-Teknik, see Magnus Hultén, 'Technology as the language of schooling: utopian visions of technology in Swedish general education in the 1960s,' International Journal of Technology and Design Education (Published online 2012). DOI: 10.1007/s10798-012-9205-9.
} 
in the traditional curriculum. ${ }^{57}$ And in this it also became a vehicle for integration and school work to be arranged in larger projects centred around central and for the student relevant themes. In short, Teknik became a tool for the Progressive Education Movement in late 1960s in Sweden. ${ }^{58}$

The change of name from Teknisk orientering to Teknik appeared late in the reform work, in November $1967 .{ }^{59}$ That the subject needed a new name seems likely, as it both had changed and that the name Teknisk orientering had been perceived as inadequate in the first place. The main reason for the name change seems to have been to find a shorter and more descriptive term. It also fitted well with the way of naming the other three optional subjects (språk, konst, ekonomi). The one in charge of the revision of the syllabus at the Board explained it as follows: 'When we sat there working with it [the name of the subject], somebody [most likely a technocrat at the Board] said that it should be named Teknik. Then I thought, could it be that simple [laugh]? ${ }^{60}$

The change of name provided the subject with a new and interesting definition, a definition found in the supplement to the 1969 national curriculum in which the subject Teknik was elaborated on more thoroughly:

\footnotetext{
${ }^{57}$ However, in the final syllabus, the integrative potential of the subject was only indirectly referred to. In the wording of the syllabus, teaching in the subject should: 'illustrate the interaction between technology (teknik) and other fields of knowledge'. The sentence appears both in the proposal from 1967 and in the final syllabus in 1969. See Skolöverstyrelsen, Läroplansöversyn grundskolan, 120 and Skolöverstyrelsen. Läroplan för grundskolan, Lgr 69 (Stockholm: Skolöverstyrelsen, 1969), 211.

${ }^{58}$ Magnus Hultén, 'Boundary objects and curriculum change: the case of integrated versus subject based teaching,' Journal of Curriculum Studies (published online 2013).

${ }^{59}$ Skolöverstyrelsen, Läroplansöversyn grundskolan, 53.

${ }^{60}$ Interview with Gösta Skoglund on 17th of January, 2009.
} 
Teaching in Technology [Teknik] should aim to provide deeper insights into the particular experiences, knowledge and skills that, taken together, are contained in the concept of technology [teknik]. ${ }^{61}$

The school subject Teknik was thus both constructed as a form of unified knowledge (not a collection of different types of technical subjects containing different types of technological knowledge, as the school subjects Teknologi or Teknisk orientering) and included technology as the prime object of study. In Teknik it was possible to talk about technological knowledge in a wide and general sense, including aesthetic, historical, gendered, science related and social aspects of technology and technological development. The aspects of technology to be studied in the subject was to be chosen mainly from a citizen perspective, such as knowledge about the washing machine, its history and social significance, how its main working principles had ben transformed by new technology across time etc. The subject was primarily promoted by teachers and technocrats but arouse little interest among engineers. For the latter actors, technical subjects were mainly associated with specific types of engineering knowledge (tekniska fackämnen), and believed to be too specific for compulsory education.

But the political importance of this new field was ambiguous. In fact, the Social Democrats finally showed little interest in promoting the subject. In 1967, a call from the Board on the minister of education, Olof Palme, who in 1969 became prime minister of Sweden, to improve the conditions for teaching in the subject was rejected with the argument that among the four eligible subjects - Language, Art, Economics and Technology - only the choice of Language would qualify a student of a working class

\footnotetext{
${ }^{61}$ Skolöverstyrelsen. Läroplan för grundskolan : Lgr 69 : del II : Supplement: kompletterande anvisningar och kommentarer : Teknik (Stockholm: Skolöverstyrelsen, 1969), 4.
} 
background for academic studies (such as engineering), and therefore, the Social Democrats' prime focus was Language. ${ }^{62}$

\section{Conclusion}

A 'technology for all' developed in the 1960s in Sweden with both political and democratic implications for citizens in a time that seemed obsessed with technology.

One factor behind the growing importance of technological knowledge in Swedish compulsory education in the 1950s and 1960s was that it proved popular among children (mainly boys) and their parents. As a popular field, it became a tool in achieving the governmental aim of securing the supply of manual workforce. Another important factor behind the increased use of the term teknik at the compulsory school level can be attributed to its seemingly neutral character. Other and contesting terms seem to have been more rigid in their meaning, making it hard for actors in the vocational education field to settle on those. Teknik was a concept that stakeholders could accept as able to embrace the diversity of the field, which at that time was rapidly changing. Also, through the school subject Teknik, it became possible to talk about different types of technologically relevant knowledge already present in other subjects in the national curriculum. Teknik thus highlighted an important dimension of the content of schooling, newer highlighted in this unified and broad way before and in this became an important tool in the Progressive Education Movement that grew in importance in Europe during this time. ${ }^{63}$

\footnotetext{
${ }^{62}$ Interview with Bertil Lydén on 13th October 2010 (telephone).

${ }^{63}$ Hultén 2013.
} 
Marx argues that the concept of 'technology' into an 'all-encompassing agent of change' in the 20th century, something that turned it into a hazardous concept. ${ }^{64} \mathrm{He}$ uses the concept of semantic void in order explain the new use of the term:

an awareness of certain novel developments in society and culture for which no adequate name had yet become available. It was this void, presumably, that the word technology eventually would fill. It would prove to be preferable — a more apt signifier-for the new agents of change than any of its precursors, received terms such as the mechanic (or useful or practical or industrial) arts, or invention, improvement, machine, machinery or mechanism. ${ }^{65}$

Technology became, Marx argues, the agent of change, 'endowed with a thing-like autonomy and a seemingly magical power of historical agency'. ${ }^{66}$ This indicate a flipped side to the development of a 'technology for all', and which can be interpreted in the framework of what Levin has termed ' $[\mathrm{t}]$ he dilemma of comprehensive secondary school reforms in Western Europe'. ${ }^{67}$ Levin argues that the post-war liberal education reforms in Western Europe had to serve dual functions:

On the one hand, they must contribute to reproducing wage labor for the systems of monopoly capitalism that dominate the Western European economies; on the other, they must represent the primary agent for providing equality and mobility to the vast majority of the populations of these countries. ${ }^{68}$

The creation of new school subjects such as Teknik, that - despite the comprehensive aims - primarily came to attract boys from the working class, and that came to have low status in the school system, in some respects meant that the inequalities of the previous

\footnotetext{
${ }^{64}$ Marx 2010, 564

${ }^{65}$ Ibid., 563.

${ }^{66}$ Ibid., 577.

${ }^{67}$ Levin, 434.

${ }^{68}$ Ibid., 444.
} 
differentiated school systems came to be recontextualized within the framework of a school 'for all'. The promise of Teknik as a 'converting ordinance' (to use the vocabulary of Popkewitz) giving a technological future to every student, paradoxically came to embody habits that enabled continued subservience for parts of the working class in relation to that same future. ${ }^{69}$ And through this perspective, this study has provided a political explanation for how the new and generally aiming subject field of technology education came to inherit a low-status vocational character. ${ }^{70}$

\footnotetext{
${ }^{69}$ Popkewitz.
}

${ }^{70}$ On the vocational tendencies in technology education today, see Alister Jones, Cathy Bunting and Marc J. de Vries, 'The developing field of technology education: a review to look forward,' International Journal of Technology and Design Education, 23, no. 2 (2013). 


\section{Acknowledgements}

This research was financed by the Swedish Research Council (Vetenskapsrådet), to which the author is grateful for support. The author would like to thank Thomas Ginner, Jan-Erik Hagberg, Jonas Hallström, Daniel Lövheim, John L. Rudolph, Martin Collins, Eric Schatzberg and anonymous referees for commenting on earlier versions of this article.

\section{Figures}

Figure 1. Flow sheet illustrating how different subjects are integrated in technological orientation. Source: Skoglund and Lydén's film Teknisk orienteering, directed by Bengt Nordsjö from 1967. 
Figure 1.

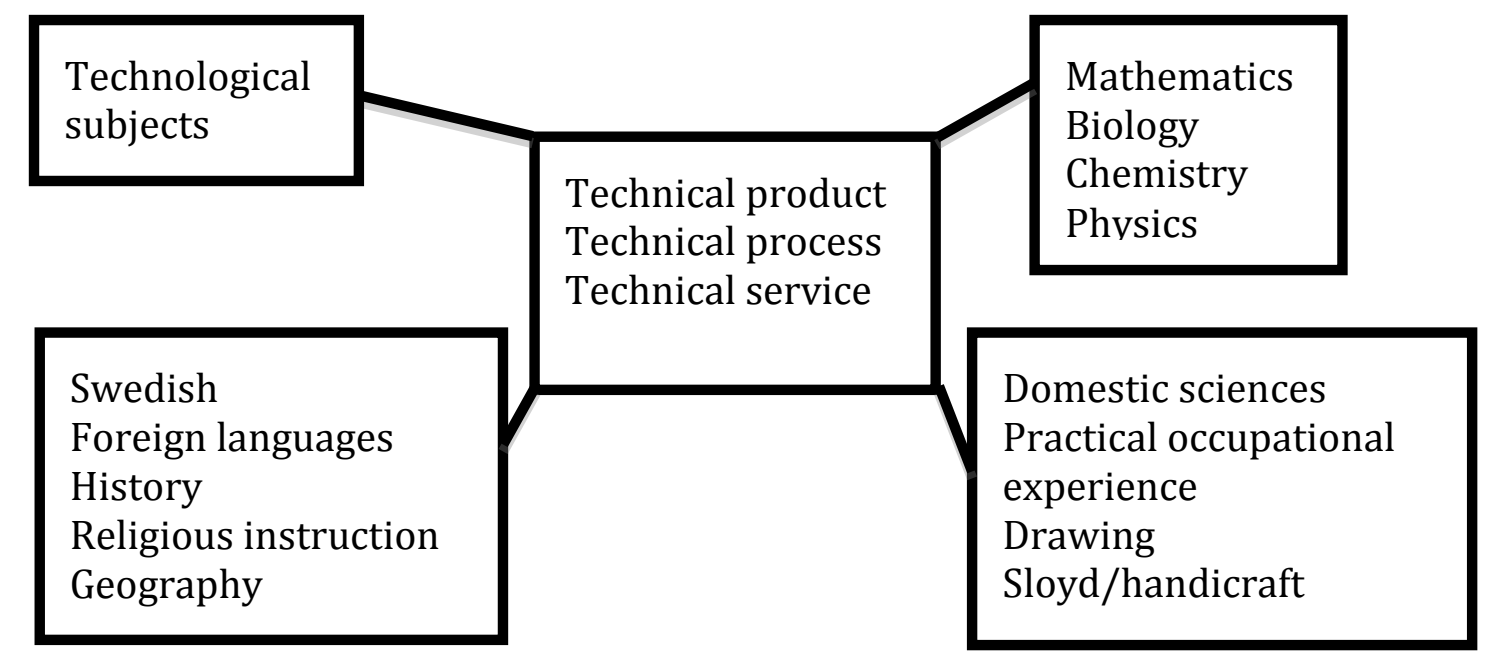

